\title{
Dietary habits of juveniles of the Mayan cichlid, Cichlasoma urophthalmus, in mangrove ponds of an offshore islet in Belize, Central America
}

\author{
Amandine Vaslet ${ }^{1}$, Christine France ${ }^{2}$, Carole C. Baldwin ${ }^{3}$ and Ilka C. Feller ${ }^{4}$
}

Foraging habitats of juveniles of the Mayan cichlid, Cichlasoma urophthalmus (Günther, 1862), were investigated in two mangrove ponds located in Twin Cays offshore islet in Belize: Sink Hole pond (SH) and Hidden Lake pond (HL). Sink Hole pond is a semiclosed body of water, whereas Hidden Lake pond is connected by a channel to adjacent seagrass beds that surround the islet. Gut contents of 21 juvenile C. urophthalmus $(9.8-13.2 \mathrm{~cm}$ total length) were analyzed, and five prey taxa were identified. In both mangrove ponds, C. urophthalmus were opportunistic carnivores and consumed primarily crustaceans. Plant material and detritus present in gut contents were most likely ingested incidentally when the fish foraged on small invertebrates. Carbon isotopic values of fish specimens from the two ponds were similar (mean \pm SD of $-19.2 \pm 0.4 \%$ in SH and $-19.4 \pm 0.4 \%$ in $\mathrm{HL}$ ), and were close to those of mangrove prey (mean $\pm \mathrm{SD}=-20.2 \pm 1.5 \%$ ), suggesting that this fish species forages in this habitat. Mixing models showed a higher contribution of mangrove food sources to the fish diet than seagrass food sources. This study reveals that young Mayan cichlids, inhabiting two Belize mangrove ponds, are generalists and opportunistic carnivores that forage on mangrove food sources and do not appear to move to adjacent seagrass beds to complement their diets. Understanding trophic linkages between aquatic consumers and food resources may contribute to better management of threatened coastal ecosystems.

Habitats de alimentação de juvenis do ciclídeo-maia, Cichlasoma urophthalmus (Günther, 1862), foram investigados em duas lagoas de mangue localizadas nas ilhas Twin Cays em alto mar em Belize: Sink Hole Lake (SH) e Hidden Lake (HL). Sink Hole é um corpo d'água parcialmente isolado, enquanto Hidden Lake é ligada por um canal com bancos de sargaços que cercam a ilhota. O conteúdo estomacal de 21 juvenil de $C$. urophthalmus $(9,8-13,2 \mathrm{~cm}$ de comprimento total) foram analisados e cinco táxons de presas foram identificados. Em ambas as lagoas de mangue, ' $C$.' urophthalmus foram carnívoros oportunistas e consumiram principalmente crustáceos. Material vegetal e detritos presentes no conteúdo digestivo foram provavelmente ingeridos acidentalmente quando o peixe se alimentava de pequenos invertebrados. Os valores de isótopos estáveis do carbono em espécimes de peixes das duas lagoas foram semelhantes (média \pm SD -19,2 $\pm 0,4 \%$ em SH e - 19,4 $\pm 0,4 \%$ em HL), e foram próximos aos de presas de mangue (mean $\pm \mathrm{SD}=-20.2 \pm 1.5 \%$ ), sugerindo que esta espécie de peixe vai à procura de alimentos neste habitat. Modelos mistos mostraram uma maior contribuição de fontes alimentares de mangue para a dieta dos peixes do que de fontes alimentares de algas marinhas. Este estudo revela que juvenis do ciclídeo-maia que habitam duas lagoas de mangue em Belize, são carnívoros generalistas e oportunistas que se ingerem alimentos dos manguezais e não parecem se mover para leitos de algas marinhas adjacentes para complementar suas dietas. Compreender as ligações tróficas entre consumidores aquáticos e recursos alimentares pode contribuir para uma melhor gestão dos ecossistemas costeiros ameaçados.

Key words: Caribbean, Cichlidae, Diet, Seagrass beds, Stable isotopes.

\section{Introduction}

The Mayan cichlid, Cichlasoma urophthalmus (Günther, 1862), is native to Atlantic Central American fresh and brackish waters from the Rio Coatzacoalcos in Mexico through the
Yucatan Peninsula and Isla Mujeres, Belize, Guatemala, Honduras, and Nicaragua (Miller, 1966; Greenfield \& Thomerson, 1997). Like most cichlids, C. urophthalmus is a euryhaline species that has the capacity to adapt throughout its life to a variety of environmental conditions. This species

\footnotetext{
${ }^{1}$ Smithsonian Marine Station at Fort Pierce, 701 Seaway Drive, Fort Pierce, Florida 34949. amandine.vaslet@gmail.com ${ }^{2}$ Smithsonian Museum Conservation Institute, 4210 Silver Hill Rd., Suitland, Maryland 20746.

${ }^{3}$ National Museum of Natural History, Smithsonian Institution, P.O. Box 37012, Washington, District of Columbia $20013-7012$.

${ }^{4}$ Smithsonian Environmental Research Center, Edgewater, Maryland 21037.
} 
seems to prefer freshwater and lower salinities, but is tolerant to wide ranges of salinity, from freshwater to marine conditions (i.e., 0 to 35) (Martinez-Palacios et al., 1990). Cichlasoma urophthalmus is also highly tolerant to fluctuations of water temperature $\left(14^{\circ} \mathrm{C}\right.$ to $28^{\circ} \mathrm{C}$ ) (Schofield et al., 2010) and can resist hypoxic conditions (dissolved oxygen $<1.0 \mathrm{mg} / \mathrm{L}$ ) by using aquatic surface respiration and buccal bubble holding techniques (Schofield et al., 2009). Therefore, this species occurs over a diversity of habitats, such as rivers, brackish lagoons, mangroves, seagrass beds and barrier reefs (Martinez-Palacios \& Ross, 1988; Greenfield \& Thomerson, 1997; Smith et al., 2003; Chávez-López et al., 2005).

Cichlasoma urophthalmus has become an effective invasive species spreading westward and northward from its native range. It is now established in freshwater and estuarine habitats of south Florida, where it is one of the most abundant exotic fish species (Trexler et al., 2000; Bergmann \& Motta, 2005). The abundance of this non-indigenous species has negative effects on native fish assemblages by inducing competitive interactions on aquatic shelters or spawning habitats, and increasing predation on nests and recruits of indigenous species (Trexler et al., 2000).

The invasive success of C. urophthmalmus is related to its generalist and opportunistic diet and its capability to adapt to novel food sources (Bergmann \& Motta, 2005). In its native habitats, C. urophthalmus is an omnivore, foraging on detritus, crustaceans and plant material (Caso Chávez et al., 1986; Chávez-López et al., 2005). In Florida, this species remains a generalist feeder throughout its ontogeny, but is more carnivorous and consumes fishes and crustaceans (Bergmann \& Motta, 2005). Due to its robust pharyngeal jaw apparatus, C. urophthalmus can also consume hard-shelled invertebrates such as gastropods. This dietary flexibility enables C. urophthalmus to forage on a diversity of prey items, which explains its rapid and successful invasion in south Florida (Bergmann \& Motta, 2005).

Some dietary partitioning has been reported in $C$. urophthalmus in its native region based on location of habitat. In three coastal lagoonal systems in Mexico, C. urophthalmus diets ranged from herbivorous (consuming predominantly plant detrital material and algae) in the Alvarado lagoon of Veracruz (Chávez-López et al., 2005); to omnivorous (ingesting plant material and crustaceans) in Términos lagoon (Caso Chávez et $a l ., 1986$ ); and to carnivorous (foraging primarily on invertebrates) in Celestún lagoon (Martinez-Palacios \& Ross, 1988). These differences again highlight the dietary flexibility of C. urophthalmus. Dietary studies conducted to date have identified the main prey consumed by $C$. urophthalmus, but no investigations have identified the habitats from which this fish species derives its food (i.e., mangroves, submerged aquatic vegetation, marshes). Some fish species that inhabit mangroves are known to forage in adjacent seagrass beds (Kieckbusch et al., 2004; Vaslet et al., 2011), where consumers are likely to forage on more diverse and more abundant food sources (Nagelkerken et al., 2008). The dietary flexibility of $C$. urophthalmus enables it to forage in a diverse array of habitats, including mangroves, but it is not known if Mayan cichlids inhabiting mangroves actually forage there.

The present study used a combination of gut-contents and stable isotope analyses (SIA) to determine the diet and foraging habitats of juveniles of C. urophthalmus in two mangrove ponds of an offshore islet in Belize, one of which is a semiclosed pond, the other connected by a channel to adjacent seagrass beds. Stable isotopes of carbon $\left(\delta^{13} \mathrm{C}\right)$ and nitrogen $\left(\delta^{15} \mathrm{~N}\right)$ have become a standard technique in food web investigations and provide insights into food sources ingested by a consumer in the preceding weeks to months (Gearing, 1991). Due to different photosynthetic pathways and inorganic carbon sources, terrestrial and aquatic macrophytes differ in their carbon signatures. Terrestrial mangrove trees using $\mathrm{C} 3$ photosynthetic pathway are more depleted in ${ }^{13} \mathrm{C}$ (on average between -30 and $-24 \%$ ) compared to submerged seagrass plants $\left(\delta^{13} \mathrm{C}>-15 \%\right.$ ) (Fry \& Sherr, 1984; Bouillon et al., 2008). Therefore $\delta^{13} \mathrm{C}$ values enable the assessment of the origin of the organic matter assimilated by consumers (Bouillon et al., 2008; Vaslet et al., 2011). The $\delta^{15} \mathrm{~N}$ values increase predictably with the trophic position (TP) of consumers which are enriched in heavier ${ }^{15} \mathrm{~N}$ relative to their prey items (Peterson \& Fry, 1987; McCutchan et al., 2003). Therefore, nitrogen isotopic values represent accurate indicators of consumers' TP in aquatic food webs and provide a spatial and temporal integrated measure of TP as nitrogen moves up the food web (Vander Zanden \& Rasmussen, 2001; Post, 2002).

The objectives of this study were (1) to assess the diet of juveniles of $C$. urophthalmus observed in two mangrove ponds; and (2) to determine whether specimens of $C$. urophthalmus exhibit different diets and feeding habitats depending on the connectivity of mangrove ponds to adjacent seagrass beds. The interior areas of mangrove systems (such as ponds and creeks) have received less scientific scrutiny in the Caribbean than exterior mangroves, but they are not less important when evaluating the role of mangroves as fish feeding grounds (Lugendo et al., 2007; Mendoza-Carranza et al., 2010) or secondary production in the fish community (Valentine-Rose et al., 2007). In these mangrove creeks or ponds, aquatic consumers are expected to rely more on in situ organic matter (i.e., mangrove food resources) due to lower connectivity between mangroves and adjacent coastal habitats (MendozaCarranza et al., 2010). A better understanding of the diet and foraging habitats of $C$. urophthalmus in its native range may help to further assess its ability to successfully invade areas outside its native distribution.

\section{Material and Methods}

The study area was located at Twin Cays (Fig. 1), a peatbased 92 ha archipelago mangrove islet located $2 \mathrm{~km}$ from the barrier reef of central Belize $\left(16^{\circ} 50^{\prime} \mathrm{N} 88^{\circ} 06^{\prime} \mathrm{W}\right)$. This islet is located $12 \mathrm{~km}$ off shore and receives no freshwater or terrigenous inputs from the mainland. An s-shaped main channel separates West and East Islands, which are characterized by a complex network of shallow channels that 


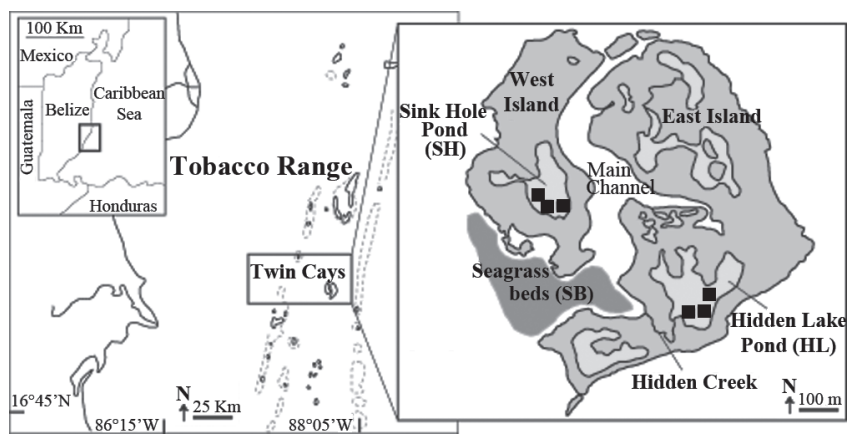

Fig. 1. Location of the two mangrove ponds (black squares), Sink Hole (SH) and Hidden Lake (HL), and the seagrass beds (grey area) sampled in the offshore islet of Twin Cays in Belize. Hidden Lake pond connects with the Main channel by the Hidden Creek.

drain standing ponds (Fig.1, Rützler et al., 2004; Urish et al., 2009). The two sampled ponds, Sink Hole Pond (SH) and Hidden Lake Pond (HL), were located on West and East Islands, respectively. These two ponds of 0.5 to $1 \mathrm{~m}$ in depth were selected due to their different configuration. On one side, $\mathrm{SH}$ is a semiclosed mangrove pond with poorly defined flow channels and characterized by a reduced hydraulic gradient for water movement due to substantial frictional resistance of mangrove roots (Urish et al., 2009). On the other side, HL pond is connected with the main channel of Twin Cays by the $20 \mathrm{~m}$ long Hidden Creek, a 3-4 m wide and 2-3 m deep channel. Around Twin Cays, the semidiurnal micro-tidal amplitude averages $15 \mathrm{~cm}$, with maximum fluctuations of 40 $\mathrm{cm}$ (Rützler et al., 2004). At low tide, water remains in the two ponds providing permanent habitat for fishes. The vegetation on Twin Cays is dominated by the red mangroves Rhizophora mangle L., which exhibit a decreasing tree-height gradient from the seaward fringe of the islet (5-6 $\mathrm{m}$ high) to the interior where dwarf trees (1-1.5 m high) dominate the landscape (Woodroffe, 1995). The bottom sediments in the ponds consist of mud, sand, detritus of plant material and carbonate silt. The sediment bottom around Twin Cays is mainly covered by the seagrass Thalassia testudinum Banks \& Soland. ex Koenig. Water salinity around Twin Cays is oceanic (i.e., 3536 ) and ranges between 22 and 38 in the ponds. Water surface temperatures average $25^{\circ} \mathrm{C}$ in January-February and $30^{\circ} \mathrm{C}$ in August (Rützler et al., 2004).

In May and June 2010, 21 specimens of C. urophthalmus were sampled along the mangrove fringe in $\mathrm{SH}$ (9 individuals) and HL (12 individuals) ponds, using fyke nets and fish traps (mesh size $6 \mathrm{~mm}$ and $12 \mathrm{~mm}$ ). Fish collected in the two mangrove ponds were measured in total length $\left(\mathrm{L}_{\mathrm{T}}\right)$ and gut contents were sorted and identified to the lowest possible taxonomic resolution. Gut contents were intended to provide a taxonomic resolution of the main prey items consumed by the fish species. The index of relative importance $(\mathrm{IRI}=(\% \mathrm{~N}+$ $\% \mathrm{~W}) * \% \mathrm{~F})$ combined the percentage of number $(\% \mathrm{~N})$, frequency of occurrence $(\% \mathrm{~F})$ and gravimetric measures $(\% \mathrm{~W})$ of prey items and was used to determine the relative contributions of food sources in the fish diet (Hyslop, 1980). Fish prey were then collected along the mangrove fringe in $\mathrm{SH}$ and HL ponds as well as in seagrass beds (SB) located outside the ponds (Fig.1). Microphytobenthos (MPB), mainly composed of benthic diatoms, was collected following the method of Riera \& Richard (1996). Plant material (litter, algae, epiphytes of seagrass leaves) and invertebrates (crustaceans, gastropods and annelids) were collected using hand nets and light traps (Table 1). All samples were rinsed with distilled water and dried at $60^{\circ} \mathrm{C}$ for at least $48 \mathrm{~h}$. Fish dorsal muscle tissues were dissected for SIA.

Stable isotope compositions of dorsal fish muscles, gastropod and crustacean muscles and entire other prey (i.e., plants, algae, amphipods, annelids) were measured with a Thermo Scientific Delta V Advantage mass spectrometer coupled to a C-N-S Costech ECS 4010 Elemental Analyser for combustion of organic material to $\mathrm{CO}_{2}$ and $\mathrm{N}_{2}$ gases. SIA were performed at the Smithsonian Institution OUSS/MCI Stable Isotope Mass Spectrometry Laboratory. Isotopic signatures are reported in delta notation in accordance with international standards: Vienna Pee Dee belemnite limestone carbonate for carbon and atmospheric air for nitrogen. SIA had a precision $\mathrm{d} \leq 0.2 \%$ for $\delta^{13} \mathrm{C}$ and $\delta^{15} \mathrm{~N}$. To account for potential differences in $\delta^{13} \mathrm{C}$ values resulting from lipid content in samples, carbon isotopic signatures of prey (gastropods, crustaceans) were mathematically normalized (Post et al., 2007). This normalization proposed a correction factor for $\delta^{13} \mathrm{C}$ based on C: $\mathrm{N}$ values (i.e., $\mathrm{C}: \mathrm{N}$ ratios $>3.5$ for lipid-rich tissue) and lipid content in animal samples (Post et al., 2007). Trophic positions (TP) of C. urophthalmus specimens from the two mangrove ponds were calculated with SIA following Post (2002), using MPB as $\delta^{15} \mathrm{~N}$ baseline, 1 as the trophic

Table 1. Mean ( \pm SD) isotopic signatures of prey items from mangrove ponds and seagrass beds. n: number of samples for stable isotope analyses.

\begin{tabular}{|c|c|c|c|}
\hline Prey items & $\mathrm{n}$ & $\delta^{13} \mathrm{C}(\%)$ & $\delta^{15} \mathrm{~N}(\%)$ \\
\hline \multicolumn{4}{|c|}{ Mangroves } \\
\hline Litter - Rhizophora mangle & 4 & $-27.3 \pm 0.3$ & $-5.7 \pm 1.4$ \\
\hline Microphytobenthos & 3 & $-16.5 \pm 0.1$ & $0.6 \pm 0.2$ \\
\hline Algae - Bostrychia sp. & 3 & $-20.6 \pm 0.6$ & $1.4 \pm 0.1$ \\
\hline Gastropods - Littorina angulifera & 3 & $-19.6 \pm 0.9$ & $1.4 \pm 0.1$ \\
\hline Annelids & 3 & $-15.8 \pm 0.3$ & $3.7 \pm 0.2$ \\
\hline Amphipods & 3 & $-16.7 \pm 0.4$ & $3.4 \pm 0.4$ \\
\hline Crab - Xanthidae & 3 & $-21.0 \pm 0.5$ & $6.5 \pm 0.8$ \\
\hline Shrimp - Penaeidae & 3 & $-21.6 \pm 0.7$ & $6.4 \pm 0.1$ \\
\hline \multicolumn{4}{|c|}{ Seagrass beds } \\
\hline Algae - Gelidiopsis sp. & 2 & $-13.1 \pm 0.4$ & $3.1 \pm 0.1$ \\
\hline Thalassia testudinum epiphytes & 5 & $-15.1 \pm 0.4$ & $3.6 \pm 0.1$ \\
\hline Annelids & 3 & $-12.6 \pm 0.3$ & $2.4 \pm 0.2$ \\
\hline Gastropods - Trochidae & 3 & $-12.1 \pm 0.1$ & $2.4 \pm 0.1$ \\
\hline Amphipods & 5 & $-12.4 \pm 0.1$ & $2.4 \pm 0.05$ \\
\hline Crabs - Porcellanidae & 4 & $-12.8 \pm 0.2$ & $3.7 \pm 0.4$ \\
\hline Crabs - Xanthidae & 4 & $-14.6 \pm 0.9$ & $4.7 \pm 0.9$ \\
\hline Shrimp - Callianassidae & 6 & $-12.4 \pm 0.7$ & $4.7 \pm 0.4$ \\
\hline
\end{tabular}


position of MPB, and a trophic enrichment of 2.2\%o for nitrogen: TP $=1+\left[\left(\delta^{15} \mathrm{~N}_{\text {fish }}-\delta^{15} \mathrm{~N}_{\mathrm{MPB}}\right) / 2.2\right]$. With MPB representing TP 1 , herbivorous and carnivorous consumers will have TP of 2 and 3 respectively.

The Bayesian mixing model SIAR v4.0 (Stable Isotope Analysis in R) developed by Parnell et al. (2010) was used to estimate relative contribution of different food sources in the diet of juveniles of C. urophthalmus. SIAR uses Bayesian inference and accounts for uncertainties associated with sample variability and trophic enrichment (Parnell et al., 2010). Trophic enrichment values due to fractionation were selected based on extensive literature review by McCutchan et al. (2003): $0.90 \pm 0.29 \%$ for carbon, based on the values obtained by Focken \& Becker (1998) for another Cichlid species, Oreochromis niloticus (Linneaus, 1758); and $2.30 \pm 0.28 \%$ for nitrogen, based on estimated enrichment values for consumers from aquatic environments. To account for the omnivorous diet of C. urophthalmus, SIAR incorporates concentration-dependence in the contributions to consider different C:N ratios between food sources (plants, animal) (Phillips \& Koch, 2002; Parnell et al., 2010; Vaslet et al., 2011). A posteriori combinations of prey contributions were determined to provide the composite contributions of sources from mangroves and seagrass beds to fish diets (Phillips et al., 2005). The data did not meet the assumptions of normality and homogeneity of variances (Shapiro-Wilks and Levene's tests). Therefore non-parametric Mann-Whitney U tests, which are generally more appropriate in small-sample cases, were used to evaluate significant differences in isotopic values between mangrove sites for fish species and between mangrove and seagrass habitats for fish food sources. Statistical significance was assigned for a $\mathrm{p}$-value $<0.05$. Statistical analyses and mixing models were performed using R (R Development Core Team, 2010).

\section{Results}

Nine and 12 specimens of C. urophthalmus were collected in $\mathrm{SH}$ and $\mathrm{HL}$ ponds, respectively, with their $\mathrm{L}_{\mathrm{T}}$ varying between 9.8 and $12.8 \mathrm{~cm}$ in SH and 10.4 and $13.2 \mathrm{~cm}$ in HL. The examination of fish gonads indicated that the specimens were juveniles. Gut content analyses were performed on 19 specimens (SH: nine specimens studied for gut contents; HL: 10 specimens studied and two had empty stomachs), and the different prey items identified in fish guts were classified into five taxonomic categories (Fig. 2). Based on IRI values, crustacean remains were the main food item consumed by fish species from SH (32.3\%) and HL ponds (45.2\%) (Fig. 2). Detritus and plant materials were of secondary importance, with IRI values lower than $30 \%$ (Fig. 2). Gastropods and annelids represented the other types of prey items ingested, with IRI values lower than $18 \%$ and $9 \%$, respectively (Fig. 2). Trophic positions were similar for the two fish assemblages (Mann-Whitney U-test: $\mathrm{df}=19, \mathrm{p}>0.05$ ) and ranged between 2.6 and 2.5 for C. urophthalmus specimens from SH and HL, respectively. These values fell between those of herbivorous

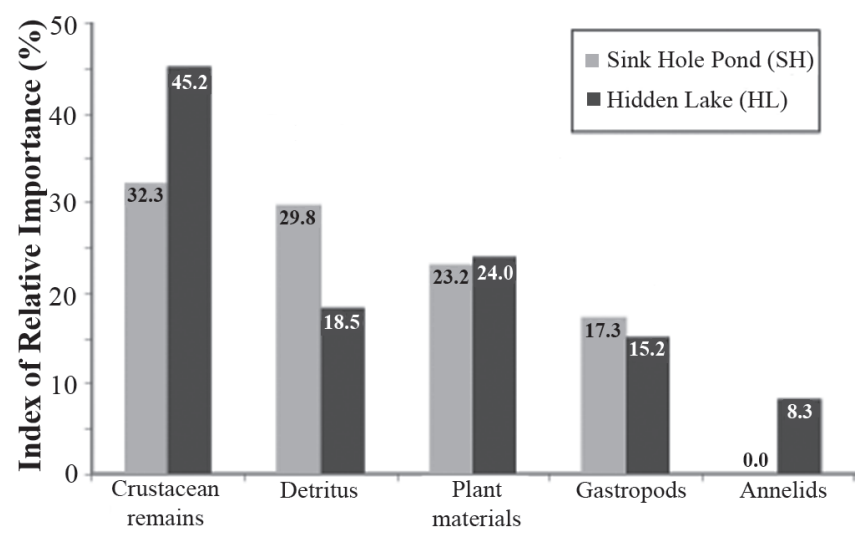

Fig. 2. Percent of index of relative importance values for Cichlasoma urophthalmus from Sink Hole and Hidden Lake ponds.

$(\mathrm{TP}=2)$ and carnivorous consumers $(\mathrm{TP}=3)$, and were consistent with $C$. urophthalmus omnivorous diet.

No significant differences in $\delta^{13} \mathrm{C}$ and $\delta^{15} \mathrm{~N}$ values were observed (Mann-Whitney U-test: $\mathrm{df}=27, \mathrm{p}>0.05$ ) between mangrove prey items from SH and HL ponds, and these food sources were grouped together as "mangrove food sources" (Fig. 3). Significant differences in $\delta^{13} \mathrm{C}$ values were observed between food sources from mangroves and those from seagrass beds, with mangrove prey items more depleted in ${ }^{13} \mathrm{C}$ (mean \pm $\mathrm{SD}=-20.2 \pm 1.5 \%$ ) than those collected in adjacent seagrass beds (mean $\pm \mathrm{SD}=-13.2 \pm 0.4 \%$, Mann-Whitney U-test: $\mathrm{df}=$ $55, \mathrm{p}<0.001$, Fig. 3 ). The $\delta^{15} \mathrm{~N}$ values were not different between mangrove and seagrass food sources (Mann-Whitney U-test: $\mathrm{df}=55, \mathrm{p}>0.05)$, but were significantly lower for plant material and $\mathrm{MPB}($ mean $\pm \mathrm{SD}=0.3 \pm 1.8 \%, \mathrm{~N}=17)$ than for invertebrates $($ mean $\pm \mathrm{SD}=3.8 \pm 0.5 \%, \mathrm{~N}=40)$ (Mann-Whitney U-test: $\mathrm{df}=$ $55, \mathrm{p}<0.001$, Fig. 3 ).

Carbon isotopic values of $C$. urophthalmus were not different (Mann-Whitney U-test: $\mathrm{df}=19, \mathrm{p}>0.05$ ) between specimens from $\mathrm{SH}$ pond (mean $\pm \mathrm{SD}=-19.1 \pm 0.6 \%, \mathrm{~N}=9$ ) and $\mathrm{HL}$ pond (mean $\pm \mathrm{SD}=-19.4 \pm 0.4 \%, \mathrm{~N}=12$ ). The same trend was observed for mean $( \pm \mathrm{SD})$ nitrogen isotopic values: $4.7 \pm 0.2 \%$ for specimens from SH and $4.9 \pm 0.2 \%$ for those from HL pond (Mann-Whitney U-test: $\mathrm{df}=19, \mathrm{p}>0.05$ ) (Fig. 3). Specimens of C. urophthalmus had $\delta^{13} \mathrm{C}$ values depleted in ${ }^{13} \mathrm{C}$ that were close to those of mangrove food sources, which suggest that this fish species consumed mangrove food sources in the two ponds (Fig. 3).

These observations were confirmed with SIAR mixing models that estimated mangrove and seagrass prey contributions to the fish diets (Fig. 4). Mangrove food sources were identified as the most important prey in the diet of specimens of C. urophthalmus from SH (64.7\% mean contributions; 51.2-78.1, 95\% Bayesian credible interval-BCI) and $\mathrm{HL}$ ponds (65.7\% mean contributions; 52.6-78.9, 95\% BCI). Seagrass prey showed lower contributions in the fish diets, with mean proportions (95\% BCI) of 35.3\% (21.8-48.7\%) for specimens from SH and $34.2 \%(21.0-47.4 \%)$ for 


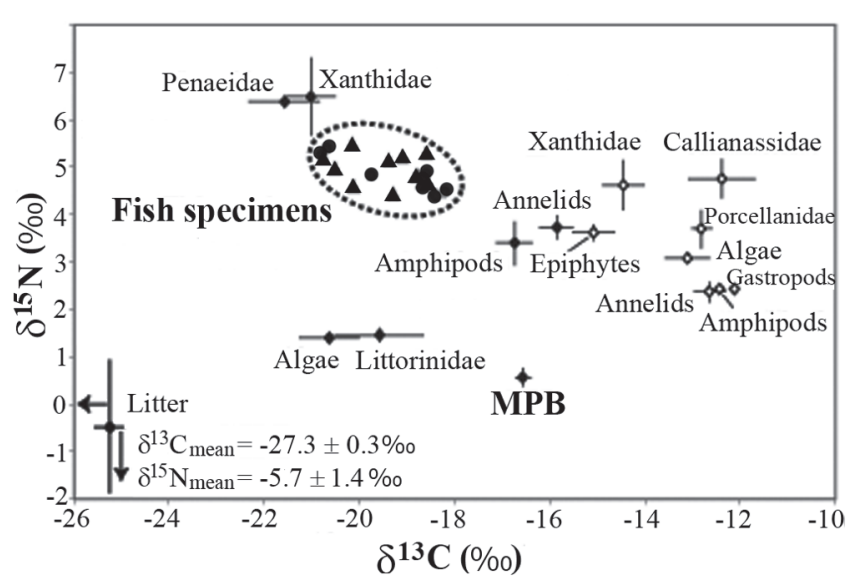

Fig. 3. $\delta^{13} \mathrm{C}$ and $\delta^{15} \mathrm{~N}$ biplot of mean values $( \pm \mathrm{SD}$ ) of Cichlasoma urophthalmus specimens from SH (grey circle) and HL (grey triangle) ponds. Mean $( \pm \mathrm{SD}$ ) isotopic signatures of food sources from mangrove ponds (black diamond) and seagrass beds (white diamond) are plotted. Dotted circle indicates isotopic values of fish specimens. Mean isotopic values $( \pm \mathrm{SD})$ of mangrove litter are reported to fit on the biplot and the observed values are indicated. MPB, microphytobenthos.

those from HL ponds. No overlap in 95\% BCI were observed between mangrove and seagrass food source contributions in the fish diet (Fig. 4).

The relatively depleted carbon values of $C$. urophthalmus and the higher proportions of mangrove prey items in the diet indicate that this species mainly forages in the two mangrove ponds where it is observed. Specimens of C. urophthalmus from HL pond did not seem to migrate to adjacent seagrass beds to complement their diet (Fig. 4).

\section{Discussion}

Like other Central American cichlids, .C. urophthalmus tolerates a wide range of environmental conditions and reveals great variation in habitat use (i.e., rivers, mangroves, estuarine systems, seagrass beds, coral reefs) (Greenfield \& Thomerson, 1997; Chávez-López et al., 2005). This environmental tolerance explains the presence of this species in two mangrove ponds located inside the offshore islet of Twin Cays (Belize), where it has been reported previously by Smith et al. (2003) and Taylor et al. (2007). In a study assessing mangrove fish assemblages in the mangrove islet of Twin Cays, Taylor et al. (2007) used nine different types of gear (including fyke nets and throw traps) and collected 16 and 3 specimens of C. urophthalmus in mangrove ponds and mangrove fringe, respectively (Taylor D.S., pers. comm.). Cichlasoma urophthalmus represented only $0.4 \%$ of the total catch in terms of abundance in the Taylor et al. (2007) study and was not one of the most common fish species. The natural abundance of this fish species in this mangrove islet and the use of only two types of sampling gear

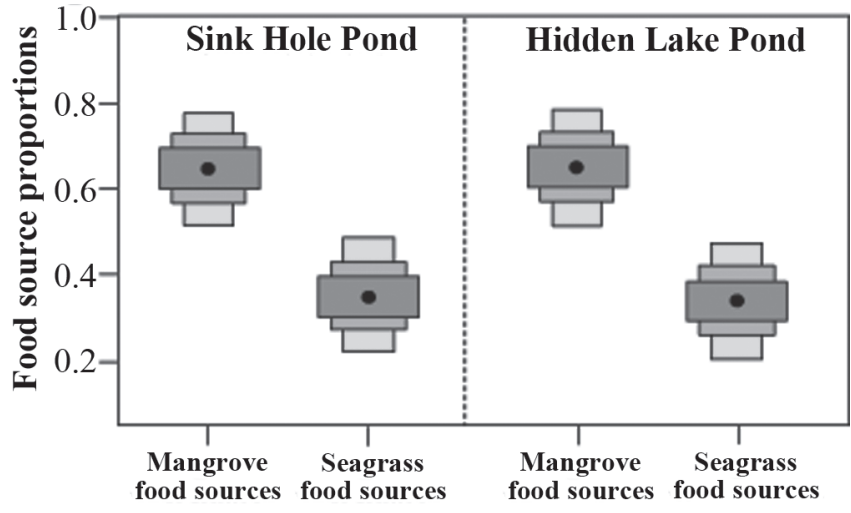

Fig. 4. Food source proportions (0-1) in the fish diets from Sink Hole and Hidden Lake ponds using SIAR mixing models. Prey items are grouped in mangrove and seagrass food sources. Means are represented by black dots and boxes indicate $50 \%$, $75 \%$ and $95 \%$ Bayesian credible intervals for means.

likely explain the low number of specimens caught in our study and the fact that the specimens were juveniles. Using a broader selection of fish-sampling gear could result in the capture of more specimens and different size ranges. However, movements of $C$. urophthalmus within the mangrove ponds and whether or not there is an ontogenetic component to patterns of movement are not known. Due to a reduced hydraulic gradient in SH semiclosed mangrove pond, it seems likely that fish species remain in this pond.

In its native area, C. urophthalmus exhibits different diets based on the diversity and abundance of food resources (Table 2). In a brackish lagoon in Celestún (Mexico), Martinez-Palacios \& Ross (1988) described C. urophthalmus as an opportunistic carnivore that feeds on small crustaceans. According their study, plant materials are ingested incidentally with small benthic invertebrates (Martinez-Palacios \& Ross, 1988). This trend also is evident in the ponds of Twin Cays, where mangrove crustaceans constitute the main food item consumed by the fish, but plant matter and detritus form a small portion of the gut contents. These observed dietary habits are consistent with previous observations of anatomical features of the Mayan cichlid, i.e., strong dentition with lower pharyngeal teeth efficient for crushing invertebrates and a short intestine that reveals a carnivorous diet (Martinez-Palacios \& Ross, 1988). Therefore, C. urophthalmus in the mangrove ponds in Belize, as well as the brackish lagoon in Celestún (Mexico), is most likely an opportunistic carnivore that ingests plant materials and detritus as a consequence of predation on benthic prey (Martinez-Palacios \& Ross, 1988; present study). The observations of $C$. urophthalmus as an herbivore or an omnivore in other Mexican lagoons (Alvarado lagoon, Chávez-López et al., 2005) likely reflects the availability of different prey items in these lagoons. Indeed, Chávez-López et al. (2005) pointed out a seasonal shift in the diet of $C$. 
Table 2. Review of gut-content analyses performed on Cichlasoma urophthalmus specimens from the Caribbean and Florida. $\mathrm{n}$, number of fish specimens studied for gut-content analyses. * Obtained with the relationships standard length-total length from FishBase (Froese \& Pauly, 2010)

\begin{tabular}{|c|c|c|c|c|}
\hline Location & Total length in $\mathrm{cm}(\mathrm{n})$ & Main prey item & Secondary prey item & References \\
\hline $\begin{array}{l}\text { Belize } \\
\text { Twin Cays }\end{array}$ & $9.8-13.2(19)$ & Crustaceans, detritus, plant material & Gastropods, annelids & This study \\
\hline \multicolumn{5}{|l|}{ Mexico } \\
\hline Terminos lagoon & $3.2-12.4(50)$ & $\begin{array}{l}\text { Crustacean remains (amphipods, crabs, } \\
\text { shrimps) }\end{array}$ & Plant material & Caso-Chávez et al. (1986) \\
\hline Alvarado lagoon & $11.4-19.1 *(105)$ & Plant material & Molluscs, crustaceans & \multirow{2}{*}{$\begin{array}{c}\text { Cháves-López et al. (2005) } \\
\text { Martinez-Palacios \& Ross } \\
\text { (1988) }\end{array}$} \\
\hline Celestún lagoon & $12.6-26.2 *(848)$ & Crustaceans & Fishes, plant material & \\
\hline \multicolumn{5}{|r|}{ 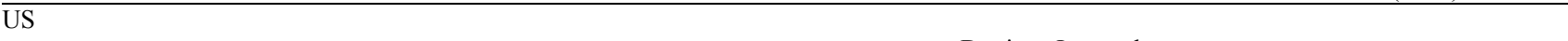 } \\
\hline South Florida & $2.2-13.2 *(136)$ & Fish, ostracods, filamentous algae & $\begin{array}{l}\text { Detritus, Insects larvae, } \\
\text { gastropods }\end{array}$ & Bergmann \& Motta (2005) \\
\hline
\end{tabular}

urophthalmus, which increase their consumption of invertebrates (crustaceans, insects, molluscs) when they become more abundant during the dry season. Therefore, Cichlasoma urophthalmus can be described as a generalist feeder and opportunistic carnivore (Martinez-Palacios \& Ross, 1988; Chávez-López et al., 2005).

In the 1970s, mangroves were described as important fish foraging habitats, with mangrove leaves at the base of a detrital food web (Odum \& Heald, 1975). Recent use of carbon and nitrogen SIA revealed that only a few fish species (mangrove resident species and only a few transient species) actually forage in mangroves and that most fish species sheltering in this habitat undergo trophic migrations in nearby seagrass beds (Kieckbusch et al., 2004; Bouillon et al., 2008; Nagelkerken et al., 2008; Vaslet et al., 2011). Previous studies were conducted primarily in fringing or open mangrove ecosystems, but interior mangrove habitats (such as creeks or ponds) have received less scientific scrutiny. In our study of interior mangrove ponds, mangrove invertebrates constituted the main food items of juveniles of $C$. urophthalmus regardless of the mangrove pond considered. Fish specimens from HL pond also fed primarily on mangrove invertebrates despite channel access to adjacent seagrass beds. These findings are consistent with those of Lugendo et al. (2007) and Mendoza-Carranza et al. (2010), who highlighted that aquatic consumers from mangrove creeks rely more on mangrove-derived organic matter due to limited access to nearby coastal habitats. In summary, our dietary and isotopic study corroborates the opportunistic carnivorous diet and highlights the importance of mangrove food sources in the diet of juveniles of $C$. urophthalmus. Further investigation is needed to determine diet and foraging habitats of adults.

The SIAR mixing model takes into account uncertainties associated with trophic enrichment, but mixing model outputs are sensitive to variation of these enrichment values (Parnell et al., 2010; Giarrizzo et al., 2011). Trophic enrichment estimates due to fractionation (F) are subject to uncertainty, partly due to diet quality, consumer age or dietary ontogeny (Caut et al., 2009). The lack of specific $F$ values for a given consumer (such as C. urophthalmus in this study) may jeopardize the results of the model, as small errors in estimates of $F$ values can lead to large errors in estimates of food source contributions to consumer diets (Caut et al., 2009; Giarrizzo et al., 2011). To enhance the precision of the mixing model it is, therefore, useful to consider behavioural, spatial and temporal variability in samples of consumers and their food sources (Giarrizzo et al., 2011). Small sample sizes (of either food resources or consumers) also can affect mixing model outputs and may lead to less precise estimates of source contributions. Future studies should encompass other size classes of juveniles and adult specimens to test the hypotheses about C. urophthalmus's diet proposed herein. Knowledge of any ontogenetic changes in the diet and foraging habitats of $C$. urophthalmus's would be particularly useful in assessing the invasive success of this species in various habitats, including mangrove ecosystems. Future studies need to be expanded to include other mangrove ponds as well as the mangrove fringe. Fish species can show temporal dietary patterns due to seasonal variation in prey abundance or due to ontogenetic trophic shifts (Bergmann \& Motta, 2005; Vaslet et al., 2011). To address questions regarding short or long-term dietary variations in fish diets, comparisons of fish isotopic values of the same tissues through time (i.e., fish muscles) or of sections from tissues with progressive growth (i.e., otoliths, scales, bones) could be important for understanding temporal utilization of food resources (Dalerum \& Angerbjörn, 2005).

Coastal and estuarine habitats are threatened by anthropogenic stressors that may influence ecosystem productivity and trophic structure (Blaber, 2007). More research on mangrove fishes is needed worldwide to determine what proportion of them relies on mangrove $v s$. adjacent habitats for food resources and how mangrove configuration (shoreline, ponds, creeks) affects fish diets. Investigations on the linkages between aquatic consumers and food resources supporting secondary production are of primary importance in the study of ecosystems functions and could greatly enhance the overall conservation and management of fisheries resources and coastal habitats (Blaber, 2007). 


\section{Acknowledgements}

The authors thank Valerie Paul, director of Smithsonian Marine Station at Fort Pierce (SMSFP), and all the staff of SMSFP for their assistance and logistic support in the field. The authors are grateful to Zach Foltz, Woody Lee from SMSFP for their help in field collections. We thank the Belize Fisheries Department for permission to collect in mangroves. This research was funded by SMSFP Postdoctoral Fellowship to Amandine Vaslet. This paper is contribution number 889 from SMSFP and contribution number 929 from Smithsonian's Caribbean Coral Reef Ecosystems Program.

\section{Literature Cited}

Bergmann, G. T. \& P. J. Motta. 2005. Diet and morpholy through ontogeny of the nonindigenous Mayan cichlid 'Cichlasoma (Nandopsis)' urophthalmus (Günther 1862) in southern Florida. Environmental Biology of Fishes, 72: 205-211.

Blaber, S. J. M. 2007. Mangroves and fishes: issues of diversity, dependence, and dogma. Bulletin of Marine Science, 80: 457-472.

Bouillon, S., R. M. Connolly \& S. Y. Lee. 2008. Organic matter exchange and cycling in mangrove ecosystems: recent insights from stable studies. Journal of Sea Research, 59: 44-58.

Caso Chávez, M. A., A. Yáñez-Arancibia \& Lara-Domínguez A. L. 1986. Biologia, ecologia y dinamica de poblaciones de Cichlasoma urophthalmus (Günter) (Pisces: Cichlidae) en habitat de Thalassia testudinum y Rhizophora mangle, Laguna de Términos, sur del Golfo de Mexico. Biotica, 11: 79-111.

Caut, S., E. Angulo \& F. Courchamp. 2009. Variation in discrimination factors $\left(\delta^{15} \mathrm{~N}\right.$ and $\left.\delta^{13} \mathrm{C}\right)$ : the effect of diet isotopic values and applications for diet reconstruction. Journal of Applied Ecology, 46: 443-453.

Chávez-López, R., M. S. Peterson, N. J. Brown-Peterson, A. A. Morales-Gómez \& J. Franco-López. 2005. Ecology of the Mayan cichlid, Cichlasoma urophthalmus Günther, in the Alvarado lagoonal system, Veracruz, Mexico. Gulf and Caribbean Research, 16: 1-10.

Dalerum, F. \& A. Angerbjörn. 2005. Resolving temporal variation in vertebrate diets using naturally occurring stable isotopes. Oecologia, 144: 647-658.

Focken, U. \& K. Becker. 1998. Metabolic fractionation of stable carbon isotopes: implications of different proximate compositions for studies of the aquatic food webs using $\delta^{13} \mathrm{C}$ data. Oecologia, 115: 337-343.

Froese, R. \& D. Pauly. 2011. FishBase. World Wide Web electronic publication. Available from: http://www.fishbase.org (08/2011).

Fry, B. \& E. B. Sherr. 1984. $\delta^{13} \mathrm{C}$ measurements as indicators of carbon flow in marine and freshwater ecosystems. Contributions in Marine Science, 27: 13-47.

Gearing, J. N. 1991. The study of diet and trophic relationships through natural abundance ${ }^{13} \mathrm{C}$. Pp. 201-218. In: Coleman, D. C. \& B. Fry (Eds.). Carbon isotope techniques. Academic Press, SanDiego.

Giarrizzo, T., R. Schwamborn \& U. Saint-Paul. 2011. Utilization of carbon sources in a northern Brazilian mangrove ecosystem. Estuarine, Coastal and Shelf Science, 95: 447-457.

Greenfield, D. W. \& J. E. Thomerson. 1997. Fishes of the continental waters of Belize. University of Florida Press, Gainsville, Florida, 311p.
Hyslop, E. J. 1980. Stomach contents analysis-a review of methods and their application. Journal of Fish Biology, 17: 411-429.

Kieckbusch, D. K., M. S. Koch, J. E. Serafy \& W. T. Anderson. 2004. Trophic linkages among primary producers and consumers in fringing mangroves of subtropical lagoons. Bulletin of Marine Science, 74: 271-285.

Lugendo, B. R., I. Nagelkerken, G. Kruitwagen, G. van der Velde \& Y. D. Mgaya. 2007. Relative importance of mangroves as feeding habitats for fishes: a comparison between mangrove habitats with different settings. Bulletin of Marine Science, 80: 497-512.

Martinez-Palacios, C. A. \& L. G. Ross. 1988. The feeding ecology of the Central American cichlid Cichlasoma urophthalmus (Günther). Journal of Fish Biology, 33: 665-670.

Martinez-Palacios, C. A., L. G. Ross \& M. Rosado-Vallado. 1990. The effects of salinity on the survival and growth of juvenile Cichlasoma urophthalmus. Aquaculture, 91: 65-75.

McCutchan, J. H., W. M. Lewis, C. Kendall \& C. C. McGrath. 2003. Variation in trophic shift for stable isotope ratios of carbon, nitrogen, and sulfur. Oikos, 102: 378-390.

Mendoza-Carranza, M., D. J. Hoeinghaus, A. M. Garcia \& A. RomeroRodriguez. 2010. Aquatic food webs in mangrove and seagrass habitats of Centla Wetland, a Biosphere Reserve in Southeastern Mexico. Neotropical Ichthyology, 8: 171-178.

Miller, R. R. 1966. Geographical distribution of central american freshwater fishes. Copeia, 1996: 773-802.

Nagelkerken, I., S. J. M. Blaber, S. Bouillon, P. Green, M. Haywood, L. G. Kirton, J. O. Meynecke, J. Pawlik, H. M. Penrose, A. Sasekumar \& P. J. Somerfield. 2008. The habitat function of mangroves for terrestrial and marine fauna: a review. Aquatic Botany, 89: 155-185.

Odum, E. P. \& E. J. Heald. 1975. The detritus based food web of an estuarine mangrove community. Pp. 265-286. In: Cronin L. E. (Ed.). Estuarine Research. Academic Press, New York.

Parnell, A. C., R. Inger, S. Bearhop \& A. L. Jackson. 2010. Source partitioning using stable isotopes: coping with too much variation. PLOS One, 5: 1-5.

Peterson, B. J. \& B. Fry. 1987. Stable isotopes in ecosystem studies. Annual Review of Ecology and Systematics, 18: 293-320.

Phillips, D. L. \& P. L. Koch. 2002. Incorporating concentration dependence in stable isotope mixing models. Oecologia, 130: 114-125.

Phillips, D. L., S. D. Newsome \& J. W. Gregg. 2005. Combining sources in stable isotope mixing models: alternative methods. Oecologia, 144: 520-527.

Post, D. M. 2002. Using stable isotopes to estimate trophic position: models, methods, and assumptions. Ecology, 83: 703-718.

Post, D. M., C. A. Layman, D. A. Arrington \& G. Takimoto. 2007. Getting to the fat of the matter: models, methods and assumptions for dealing with lipids in stable isotope analyses. Oecologia, 152: 179-189.

R Development Core Team. 2010. R: A Language and Environment for Statistical Computing. Version 2.14.0 ${ }^{\circledR}$.

Riera, P. \& P. Richard. 1996. Isotopic determination of food sources of Crassostrea gigas along a trophic gradient in the estuarine Bay of Marennes-Oléron. Estuarine, Coastal and Shelf Science, 42: 347-360.

Rützler, K., I. Goodbody, M. Cristina Diaz, I. C. Feller \& I. G. Macintyre. 2004. The aquatic environment of Twin Cays, Belize. Atoll Research Bulletin, 512: 1-48.

Schofield, P. J., W. F. Loftus \& J. A. Fontaine. 2009. Salinity effects on behavioural response to hypoxia in the non-native Mayan 
cichlid Cichlasoma urophthalmus from Florida Everglades wetlands. Journal of Fish Biology, 74: 1245-1258.

Schofield, P. J., W. F. Loftus, R. M. Kobza, M. I. Cook \& D. H. Slone. 2010. Tolerance of nonindigenous cichlid fishes (Cichlasoma urophthalmus, Hemichromis letourneuxi) to low temperature: laboratory and field experiments in south Florida. Biological Invasions, 12: 2441-2457.

Smith, C. L., J. C. Tyler, W. P. Davis, R. S. Jones, D. G. Smith \& C. C. Baldwin. 2003. Fishes of the Pelican Cays, Belize. Atoll Research Bulletin, 497: 1-88.

Taylor, D. S., E. A. Reyier, C. C. McIvor \& W. P. Davis. 2007. An assessment of ichthyofaunal assemblages within the mangal of the Belize offshore cays. Bulletin Marine Science, 80: 721-737.

Trexler, J. C., W. F. Loftus, F. Jordan, J. J. Lorenz, J. H. Chick \& R. M. Kobza. 2000. Empirical assessment of fish introductions in a subtropical wetland: an evaluation of contrasting views. Biological Invasions, 2: 265-277.

Urish, D. W., R. M. Wright, I. C. Feller \& W. Rodriguez. 2009. Dynamic hydrology of a mangrove island: Twin Cays, Belize. Smithsonian Contributions to the Marine Science, 38: 473-490.

Valentine-Rose, L., J. A. Cherry, J. J. Culp, K. E. Perez, J. B. Pollock, D. A. Arrington \& C. A. Layman. 2007. Floral and faunal differences between fragmented and unfragmented bahamian tidal creeks. Wetlands, 27: 702-718.

Vander Zanden, M. J. \& J. B. Rasmussen. 2001. Variation in $\delta^{15} \mathrm{~N}$ and $\delta^{13} \mathrm{C}$ trophic fractionation: implications for aquatic food web studies. Limnology and Oceanography, 46: 2061-2066.

Vaslet, A., C. France, D. L. Phillips, C. I. Feller \& C. C. Baldwin. 2011. Stable-isotope analyses reveal the importance of seagrass beds as feeding areas for juveniles of the speckled worm eel Myrophis punctatus (Teleostei: Ophichthidae) in Florida. Journal of Fish Biology, 79: 692-706.

Woodroffe, C. D. 1995. Mangrove vegetation of Tobacco Range and nearby mangrove ranges, Central Belize Barrier Reef. Atoll Research Bulletin, 427: 1-35.

Submitted December 12, 2011

Accepted September 5, 2012

Published September 28, 2012 